Available online at

http://journal.ugm.ac.id/jifnp

\title{
Potential of Liquid Smoke from Palm Kernel Shell as Biopreservative to Tuna (Thumnus sp.) Fish Protein
}

\author{
Musrowati Lasindrang ${ }^{*}$ \\ ${ }^{1)}$ Department of Food, Universitas Negeri Gorontalo, Gorontalo, Indonesia \\ ${ }^{*}$ Corresponding author, email address: atik.environmentalscience@gmail.com
}

Received 23 Jan 2017; Accepted 12 May 2017; Published Online 15 May 2017

\begin{abstract}
The purpose of this research was to evaluate the role of liquid smoke of oil palm kernel as bio-preservative on the fish during storage toward chemistry/biochemical or microbiological change at to tuna (Thunnus $s p$ ) fish.This research was carried out in three steps: 1) Making liquid smoke with temperature pirolysis $400^{\circ} \mathrm{C}$ during 90 minutes and liquid smoke fractionation in rank: $\mathrm{F} 1$ : liquid temperature $100^{\circ} \mathrm{C} ; \mathrm{F} 2: 101-125^{\circ} \mathrm{C} ; \mathrm{F} 3$ : $126-150^{\circ} \mathrm{C}$; F4: $151-200^{\circ} \mathrm{C}$; 2) Proximate analysis of liquid smoke $\mathrm{FO}$ and Fraction $\mathrm{F} 2$ to tuna fish that analysed with TVB, total bacterium, and total protein content. The result indicates that the phenol and acid content was more increase with higher fractionation temperature while the carbonyl content was more reduced with higher fractionation temperature. The TVB value for Tuna fish muscle without soaking higher liquid smoke ( $38.93 \mathrm{mg} \mathrm{N} / 100 \mathrm{~g}$ and $36.27 \mathrm{mg} \mathrm{N} / 100 \mathrm{~g}$ ) compared to tuna fish muscle of liquid smoke soaking (F0) that is $13.87 \mathrm{mg} \mathrm{N} / 100 \mathrm{~g}$ and $11.73 \mathrm{mg} \mathrm{N} / 100 \mathrm{~g}$ and also soaking with F2 fraction muscle tuna $12.27 \mathrm{mg} \mathrm{N} / 100 \mathrm{~g}$. Total bacterium $\left(2.67 \times 10^{9} \mathrm{cfu} / \mathrm{g}\right.$ and $\left.2.10 \times 10^{9} \mathrm{cfu} / \mathrm{g}\right)$ compare without soaking liquid smoke (F0) and F2 fraction that is $\left(8.43 \times 10^{5} \mathrm{cfu} / \mathrm{g}\right.$ and $\left.6.23 \times 10^{5} \mathrm{cfu} / \mathrm{g}\right)$ and $\left(8.57 \times 10^{5} \mathrm{cfu} / \mathrm{g}\right.$ and $\left.6.50 \times 10^{5} \mathrm{cfu} / \mathrm{g}\right)$.
\end{abstract}

Keywords: liquid smoke, palm kernel shell, biopreservative, Tuna fish

\section{Introduction}

Indonesia is the greatest palm kernel producing countries in the world after Malaysia. In addition to producing high oil palm kernel as of 10.2 million or $36.32 \%$ of total world palm kernel production it also produces waste of palm kernel factory. Commonly, waste of palm kernel factory consist of liquid, solid and gas waste (Wahyono et al., 2004). Solid waste particularly palm kernel shell has actually benefits. One of them is liquid smoke resulted from pyrolisis process of palm kernel shell that can be used as biopreservative as substitution for chemical preservative and also tar and charcoal.
Liquid smoke is produced with dry distillation process from biomass particle at $150-400^{\circ} \mathrm{C}$. The liquid smoke produced contain highly acid and also other dominant compounds such as phenol and carbonyl that together with acid play role as carrier of specific aroma, taste and colour. The compound has antimicrobial and antioxidant effects so it is called as bio-preservative.

Use of liquid smoke as substitution of traditional smoking has developed fast. Fish smoking is a processing method resulting in yellow or reddish brown smoked fish.

Smoking can preserve fish, due to compound component contained in smoke as biopreservative. According to Pszczola (1995) 
two main compounds of liquid smoke having bactericidal/bacteriostatic effect is phenol and organic acid. In their combination, both compounds work effectively to hamper microbe growth.

Fish and other fishery products included in food stuff are easy to degrade due to high water content so microorganism is easy to grow naturally and fish contain enzyme that can decompose protein to be putrescine isobutylamine, cadaverine and others causing bad odor and fish fat contain multiple unsaturated fat acid that is easy for oxidation or hydrolysis process resulting in pungent odor. Loose composition of fish cell tissue cause microbe can be used easily as growth media so fresh or processed fishery product including smoked fish stored will undergo physical, chemical, microbiological changes that affect its quality and storage age.

However, traditional smoking process done with direct smoke of wood firing has many weaknesses such as inconsistent quality, taste and aroma. In addition, difficulty in controlling its process and companied toxic compound PAH (polycyclic aromatic hydrocarbon) that harm health. Use of liquid smoke as one of fish preservation methods can deal with the weak traditional smoking.

There is harmful and toxic compound in liquid smoke, so liquid smoke should be purified by separating/reducing the compound. One of separation/reduction method is fractionation. Fractionation was done by separating existing component based on difference in boiling point.

This research was done by studying tuna muscle damage process both its red meat and white meat particularly its protein during storing and what is role of palm kernel shell liquid smoke as biopreservative in the tuna muscle during storage. Chemical or biochemical, and microbiological changes during its storage are factor playing important role in determination of duration of acceptable muscle condition. Basic information on chemical and microbiological condition of muscle fish during storage can be uses as reference in doing analysis on shelf life of smoked fish preserved with liquid smoke palm kernel shell.

\section{Materials and Methods}

Material used is palm kernel solid waste resulted from palm kernel plantation PTPN IV Pabatu, TebingTinggi, North Sumatera. Fish used was from TPI Semarang. Size of fish is same with average weight of $500 \mathrm{~g} /$ fish.

Tools used for pyrolisis process are pyrolisis equipment including reactor tube, heater, smoke channeling pipe and condenser. Chemical component of liquid smoke was identified using GC-MS (shimadzu QP-5000)

\section{Liquid smoke Preparation and Fractionation}

Five kilograms solid waste of dry palm kernel was entered into pyrolisis reactor. Pyrolisis process was done at $400^{\circ} \mathrm{C}$ for $90 \mathrm{~min}$ and was fractioned gradually with following criteria: F0: liquid smoke; F1: temperature up to $100^{\circ} \mathrm{C}$; F2; temperature $101^{\circ} \mathrm{C}-125^{\circ} \mathrm{C}$; F3: temperature $126-150^{\circ} \mathrm{C}$; $\mathrm{F} 4$ temperature $151-$ $200^{\circ} \mathrm{C}$. Chemical composition analysis of liquid smoke and its fractions include phenol contain analysis, using Senter et al., (1989) method, carbonyl contain analysis, using Lappin and Clark (1951) method and acid contain analysis using titration method (AOAC, 1990)

\section{Study of Liquid Smoke Intervention and Fraction F2 $\left(101-125^{\circ} \mathrm{C}\right)$ as Biopreservation on Muscle of Tuna During Storage at Room Temperature}

Muscle Tuna cleaned from head, bone, stomach contain, tail and other was washed using sterile cold water (sterilized Aqua) then. Its muscle fish is separated and cut into $7 \mathrm{~cm}$ 
length and 4.5 width. Each is treated as follows: without soaking with liquid smoke (control), soaking at liquid smoke (FO), and soaking with selected fraction (F2). At 3.3\% concentration 30x thinning it was soaked for 1 h. Each treatment is stored in sterile contained at room temperature and analyzed every day up to five days. Analysis was done on total volatile based (TVB) (Apriyanto et al., 1989), total Bacteria (APC) with agar method, and total protein level (AOAC, 1990).

\section{Results and Discussion}

\section{Pyrolisis Result}

Palm kernel shell pyrolisis at $400^{\circ} \mathrm{C}$ resulted in 2500 liquid smoke component (while its charcoal was $1500 \mathrm{~g}$ and tar 430 $\mathrm{mL})$.

Table 1. Component of palm kernel liquid smoke (5 kg shell weight)

\begin{tabular}{cc}
\hline Component & Quantity \\
\hline Liquid smoke & $2500 \mathrm{~mL}$ \\
Charcoal & $1500 \mathrm{~g}$ \\
Tar & $430 \mathrm{~mL}$
\end{tabular}

Result obtained in Table 1 is caused by palm kernel shell used in the research has optimal water content (13\%) with temperature and time determined in pyrolisis process so its heat conductivity is greater. Pyrolisis process is perfect so resulted in most liquid smoke and tar, and pyrolisis resulted in relatively little charcoal. Maga (1987) and Girrard (1992) suggest that pyrolisis process involve reaction process of decomposition, oxidation, depolymerization and condensation. Processes of water elimination at $120-150^{\circ} \mathrm{C}$, hemicellulose pyrolisis at $200-$ $250^{\circ} \mathrm{C}$, cellulose pyrolisis at $280-320^{\circ} \mathrm{C}$ and lignin pyrolisis at $400^{\circ} \mathrm{C}$ result in compound having high organoleptic quality compound and higher temperature will cause condensation reaction that form new compound and condensation product oxidation was followed with increase in tar compound and polycyclic aromatic hydrocarbon.

Effort to eliminate or reduce $\mathrm{PAH}$ component of benzo(a)pyrene in liquid smoke by minimizing accompanied tar compound in liquid smoke by redistillation liquid smoke resulted in temperature that can evaporate main component of liquid smoke (organic acid, phenol and carbonyl) but not evaporate tar compound so resulted in total redistillationtar free liquid smoke. According to Gorbatov et al., (1971), one of fractionation methods is liquid smoke redistillation to eliminate tar compound and PAH.

\section{Analysis of Liquid Smoke Chemical Composition and Its Fraction}

Phenol compound content of palm kernel shell liquid smoke and its fraction in Fig. 1. 


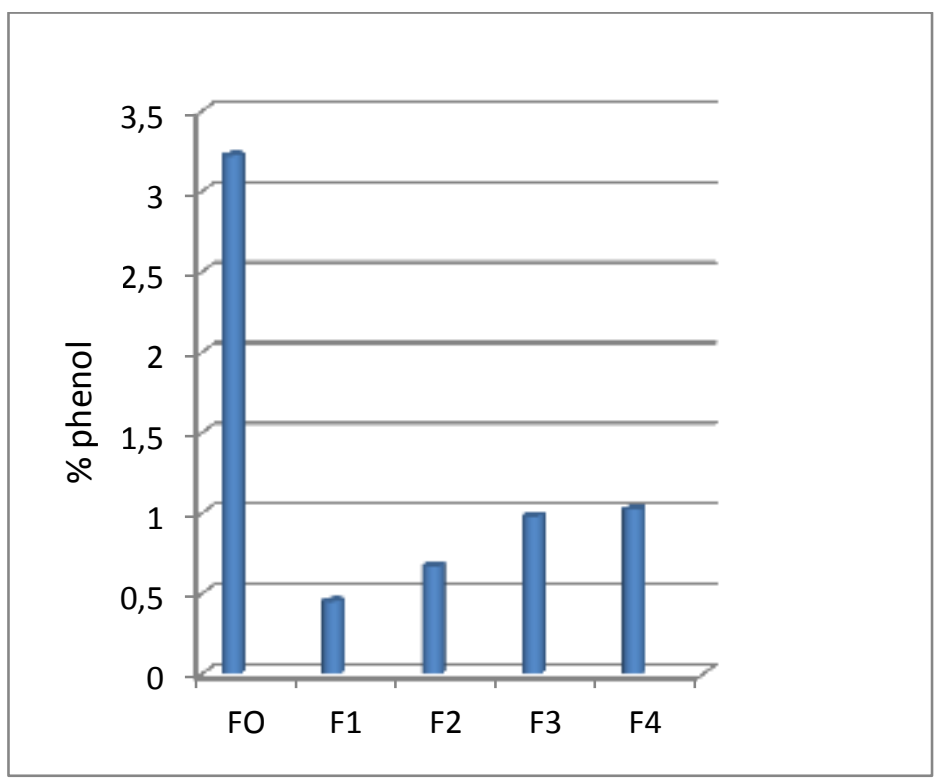

Fig. 1 Phenol compound content of palm kernel shell liquid smoke and its fraction

Result of phenol analysis indicate that FO result in the most phenol ( $F 0=3.22 \%$; $F 1=0.45 \%, F 2=0.67 \% ; F 3=0.98 \% ; F 4=1.02 \%)$. Result of fractionation indicated that its phenol contain is lower than liquid smoke. It is caused by phenol compound has higher boiling point and fractionation result using low temperature so resulted in lower phenol from control liquid smoke (FO). However, there is tendency its phenol contain increase along with increase fractionation temperature. Phenol level on FO liquid smoke is due to FO that is total phenol from its fractionation result. According to Buckingham (1982) phenol boiling point was $162-285^{\circ} \mathrm{C}$ so the higher fractionation temperature the higher its phenol.Carbonyl compound contain from palm kernel shell liquid smoke and its fraction at Fig. 2.

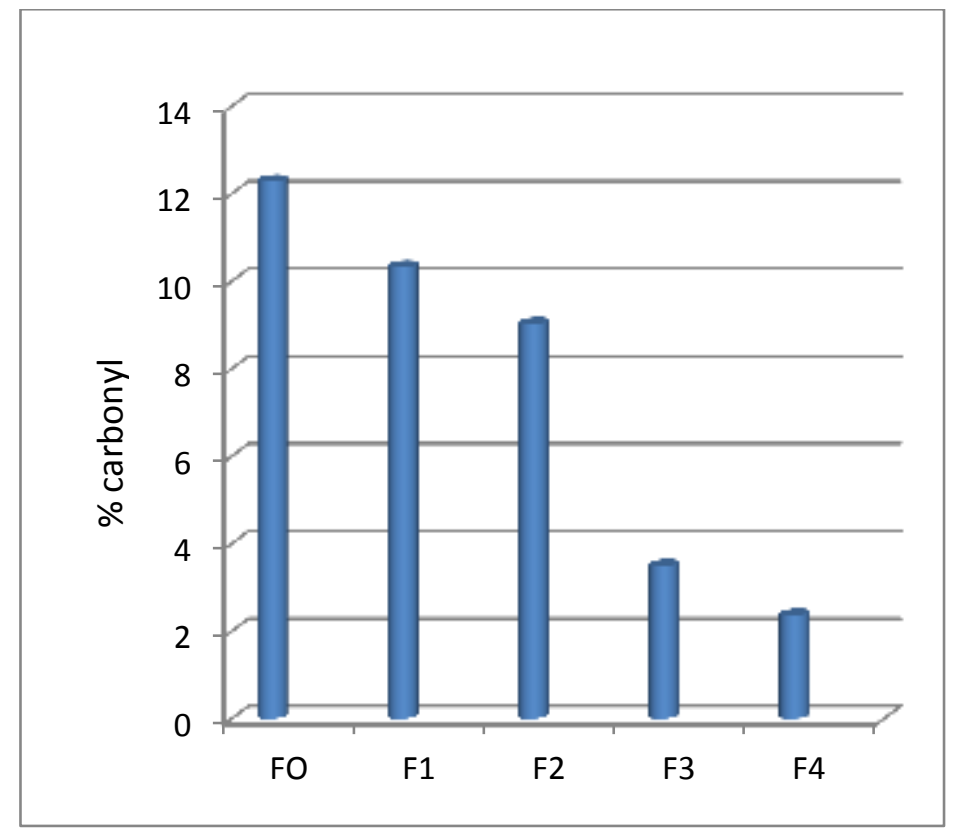

Fig. 2 Carbonyl compound contain from palm kernel shell liquid smoke and its fraction 
Result of carbonyl test from palm kernel shell liquid smoke indicated its content of $12.28 \%$. Cellulose content on palm kernel shell is lower (32.93\%) than cellulose content of coconut shell (38.98\%) so carbonyl content of palm kernel shell liquid smoke is higher due to cellulose content at the material will result in carbonyl. High cellulose content will result in high carbonyl. At palm kernel shell liquid smoke carbonyl content is greater than phenol. According to Girrard (1992) phenol has carbonyl group that is considered as carbonyl.

For its fractionation result, carbonyl level is lower than liquid smoke (FO) (12.28\%). The great carbonyl content on liquid smoke is influenced by lignin content, cellulose in oilpalm shell due to carbonyl compound is result of fractionation of the component and is raw material having high cellulose content will result in high carbonyl content due to high heating treatment in cellulose will result in carbonyl. Results of fractionation at F1, F2, F3, F4 indicated that higher temperature result in reduced carbonyl content. It is due to boiling point of carbonyl is the lowest among three main components of liquid smoke (less than $100^{\circ} \mathrm{C}$. According to Buckingham (1982) in general carbonyl has boiling point less than $100^{\circ} \mathrm{C}$. Acid compound content of palm kernel shell liquid smoke and its fraction at Fig. 3.

Result of fractionation acid level analysis indicated that result of fraction $\mathrm{F} 1$ is lower than F2, F3 and F4 (3.83\%; 9.83\%; $24 ; 43 \% ; 43.51 \%)$. It is due to acid compound of liquid smoke consisting of short, moderate and long chain acid compound. Higher temperature results in cut of moderate and long chain acid compound. So, higher temperature will cause greater acid content. Acid content in oil-palm shell liquid smoke
(FO) of $8.99 \%$ was lower than acid content of coconut shell liquid smoke of $11.39 \%$. The difference is cause by difference in cellulose content at both materials. Cellulose content of oil-palm shell and coconut shell were $32.93 \%$ and $38.98 \%$, respectively. Its content of oil-palm shell is lower than coconut shell because acid compound is result of cellulose component fractionation. According to Maga (1987) cellulose pyrolisis result in acetate acid compound and carbonyl compound such as acetaldehyde, glyoxal andacrolein. Then Girrard (1992) suggested that cellulose content in material will determine acid, furan, phenol and water content in the liquid smoke produced. It is estimated that cellulose in oilpalm shell liquid smoke (FO) result in high carbonyl content and low acid compound (8.99\%).

Benzo(a)pyrene content analysis using GC-MS of palm kernel shell liquid smoke sample was $15.82 \mathrm{ppm}$ while benzo(a)pyrene at fractionation $\mathrm{F} 2$ at $101-125^{\circ} \mathrm{C}$ was $0 \mathrm{ppm}$. According to Sax and Sax and Lewis (1987) benzo(a)pyrene is polycyclic aromatic hydrocarbon (PAH) compound group with five benzene rings found in coal tar, cigarette smoke and atmosphere as imperfect burning. Further, benzo(a)pyrene is yellow crystal with melting point of $179^{\circ} \mathrm{C}$ and boiling point 310$312^{\circ} \mathrm{C}$. It agrees to result of research where fractionation used is $\mathrm{F} 2$ at $101-125^{\circ} \mathrm{C}$ that resulted in $0 \mathrm{ppm}$ benzo(a)pyrene that is safely used as biopreservative at tuna. Acceptable maximal level of benzo(a)pyrene in food is $10 \mathrm{ppb}(10 \mu \mathrm{g} / \mathrm{kg})$, so it is necessary to look for save limit for liquid smoke usage in food by doing thinning. In this research, thinning was done 30 times and $1 \mathrm{~h}$ soaking time so liquid smoke is safe for use in tuna. 


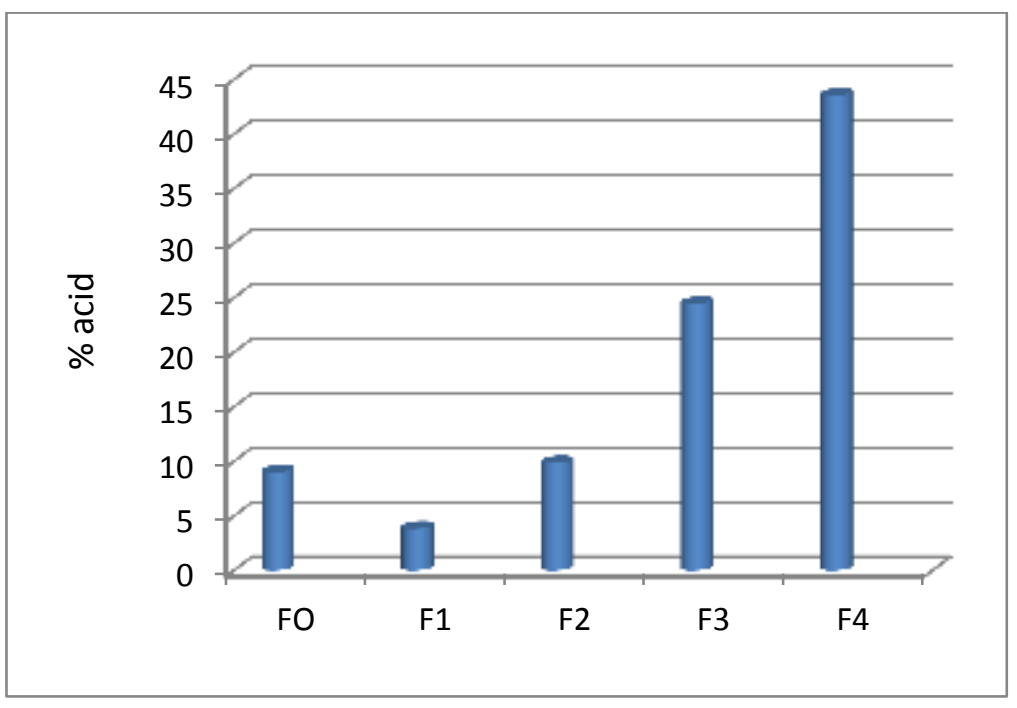

Fig. 3 Acid compound content of palm kernel shell liquid smoke and its fraction

\section{Study of Liquid Smoke Intervention and}

Fraction F2 (Temperature $101-125^{\circ} \mathrm{C}$ ) as Biopreservative in Tuna During Storage at

\section{Room Temperature}

At Fig. 4 TVB value for tuna without soaking with liquid smoke indicated increased in TVB during storage. At 0 and 5 days storage, TVB scores are $3.73 \mathrm{mg} \mathrm{N} / 100 \mathrm{~g}$ and $36.27 \mathrm{mg} \mathrm{N} / 100 \mathrm{~g}$, respectively. Tuna with soaking at palm kernel shell liquid smoke (FO) can be still consumed because TVB until day 5 was $11.73 \mathrm{mg} \mathrm{N} / 100 \mathrm{~g}$. it is due to liquid smoke has smoke component that play role as antibacterial and antioxidant including phenol and acid that can hamper microbe growth that can react directly with cell membrane causing increase in cell membrane permeability causing lost cell content, inactivation of essential enzymes and genetic material function inactivation. The higher phenol concentration will precipitate microbe protein effectively (Estrada et al, 1998).

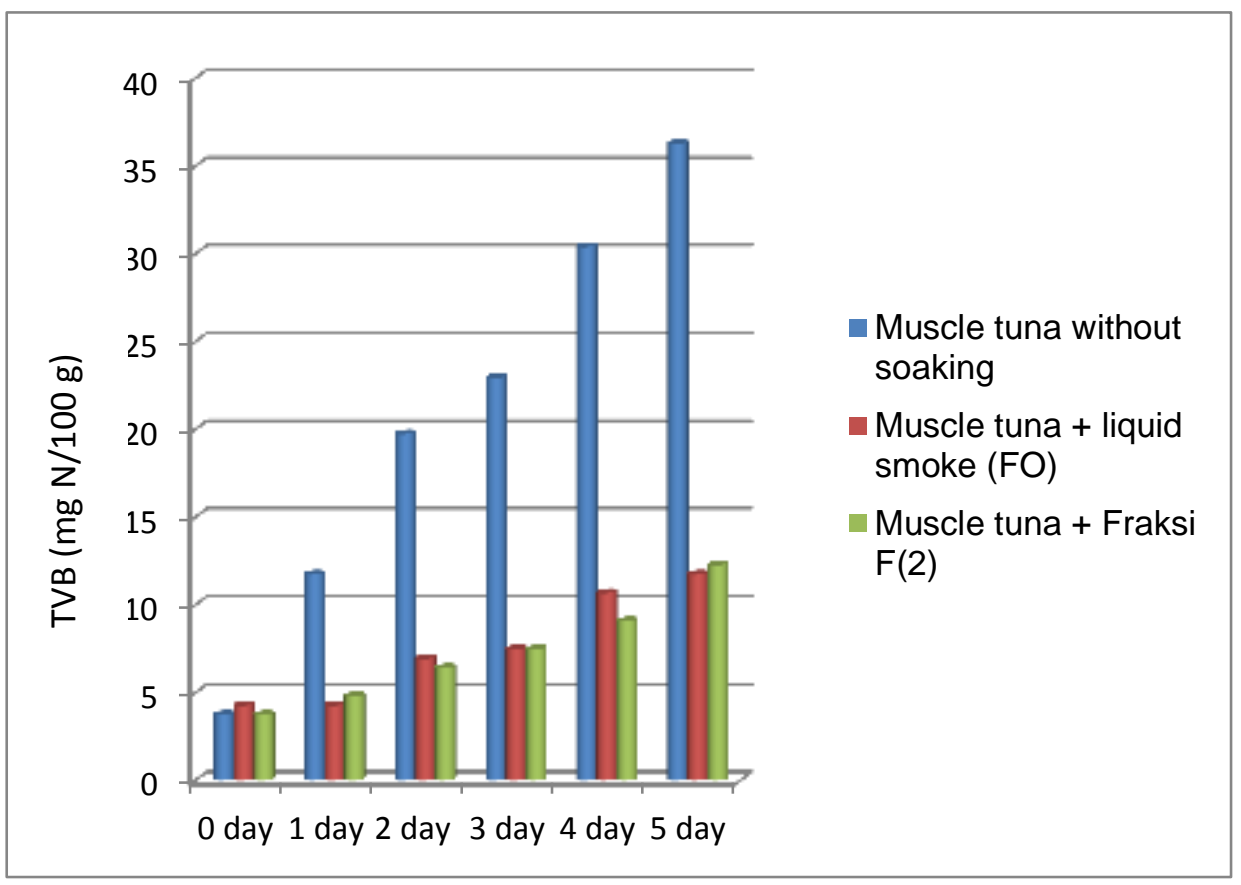

Fig. 4 Histogram of volatile base score of tuna without soaking, soaking with liquid smoke (FO), and soaked with fraction F2 
TVB value of tuna soaked at liquid smoke fraction F2 from $0-5$ days storage indicate hamper of damage due to $\mathrm{F} 2$ contain acetic acid and phenol component functioning as antibacterial agent causing bacteria's loss survivability so soaking with fraction 2 liquid smoke stored until 5 days is consumable because its TVB is only $12.27 \mathrm{mg} \mathrm{N} / 100 \mathrm{~g}$. However, at day 5 TVB increase due to liquid smoke (F0) or fraction F2 liquid smoke with 30 time thinning. So, storing till 5 days indicate decrease in inactivation by smoke component over microorganism decomposing protein or other compound containing nitrogen with increase base-base volatile resulted from bacteria decomposition. According to Darmadji (1996) acid and phenol improve antibacterial activity. Then, Swastawati et al., (2007) suggested that phenolic compound has oxidative effect and antibacterial effect that is very effective used in preserving fish because it can add shell life of fish more than 4 days,

Result of statistic test of tuna meat without soaking indicated change in TVB and significantly different $(p \leq 0.01)$ with tuna soaked in palm kernel shell liquid smoke (FO) and that soaked with fraction F2 liquid smoke.

Further analysis with Duncan test of tuna without soaking with liquid smoke is significantly different $(p \leq 0.05)$ from tuna soaked with liquid smoke (FO) and soaked with F2 liquid smoke.

\section{Total Bacteria}

At Fig. $\mathbf{5}$,total bacteria of muscle tuna without soaking in palm kernel shell liquid smoke increase during storage 0 day and 5 day are $3.47 \times 10^{5} \mathrm{cfu} / \mathrm{g}$ and $2.10 \times 10^{9} \mathrm{cfu} / \mathrm{g}$. according to Frazier and Westhoff (1983) the fish indicate degradation when total bacteria more than $10^{6} \mathrm{cfu} / \mathrm{g}$. Analysis on total bacteria at day 2 indicate that tuna without soaking with liquid smoke have degradation and is not consumable. Total bacteria of tuna soaked at liquid smoke (FO) during 0-5 days storage indicate antibacterial activity, so until day 5 total bacteria was $6.23 \times 10^{5} \mathrm{cfu} / \mathrm{g}$ in which the tuna is consumable. At fraction F2 at $0-4$ days storage degradation hamper occur because component playing role as antibacterial is phenol group and acid particularly acetic acid having boiling point of $118^{\circ} \mathrm{C}$. There is no increase in bacterial amount at tuna in 0-4 day indicate effect of fraction F2 liquid smoke residue playing role in hampering bacteria. Meanwhile at day 5 total bacteria increase to $6.50 \times 10^{5} \mathrm{cfu} / \mathrm{g}$, but it is still consumable.

Decreased hamper at day 5 is due to acetic acid of $9.83 \%$ that is antimicrobial compound in F2 liquid smoke. Antimicrobial in liquid smoke decreased because it used by bacteria, so antibacterial activity of fraction F2 liquid smoke will decrease causing increase in total bacteria at day 5 storage. Higher resistance of Escherichia coli compared with three other bacteria is due to the bacteria may used acetic acid as single carbon source for its life.

Statistical analysis on amount of bacteria in tuna without liquid smoke soaking, soaking with liquid smoke (FO) and soaking with fraction F2 liquid smoke indicated significant difference $(p \leq 0.01)$

Further analysis with Duncan test of tuna without soaking with liquid smoke is significantly different $(p \leq 0.05)$ from tuna soaked with liquid smoke (FO) and soaked with F2 liquid smoke. 


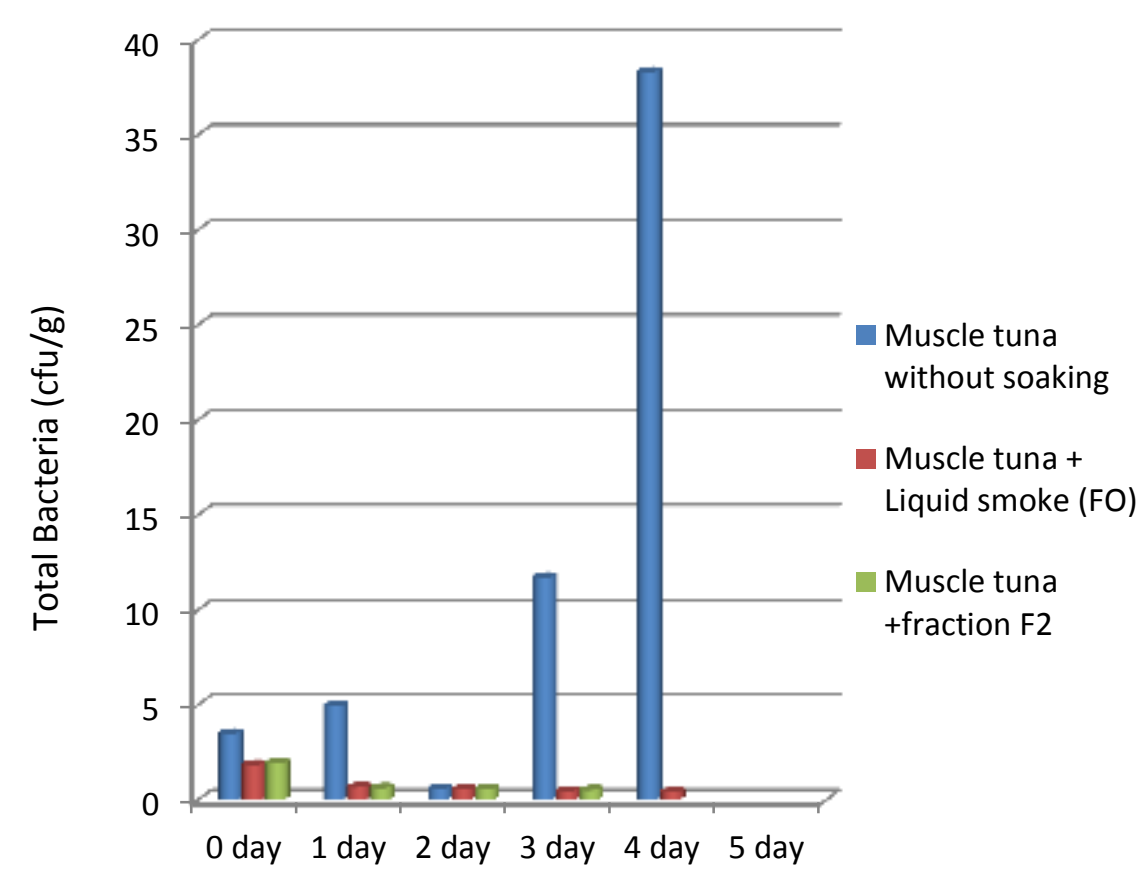

Fig. 5 Histogram of total bacteria of tuna without soaking, soaking with liquid smoke (FO), and soaked with F2

\section{Conclusion}

Based on results of the research the following conclusions are palm kernel shell liquid smoke and fractionation F2 result can play role as biopreservative for tuna fish and capability of palm kernel shell liquid smoke to hamper protein degradation of tuna affect TVB, bacteria total at storage until 5 day. Increase in TVB of tuna without liquid smoke soaking, with liquid smoke (FO) soaking and fraction $\mathrm{F} 2$ are $36.27 \mathrm{mg} \mathrm{N} / 100 \mathrm{~g}, 11.73 \mathrm{mg}$ $\mathrm{N} / 100 \mathrm{~g}$, and $12.27 \mathrm{mg} \mathrm{N} / 100 \mathrm{~g}$, respectively. Increase in total bacteria of tuna without liquid smoke soaking, soaking with liquid smoke (FO) and fraction $\mathrm{F} 2$ are $1.10 \times 10^{9} \mathrm{cfu} / \mathrm{g}$, $6.23 \times 10^{5} \mathrm{cfu} / \mathrm{g}$, and $6.50 \times 10^{5} \mathrm{cfu} / \mathrm{g}$. Phenolic content increase along with increase in fractionation temperature. Carbonyl content decrease with increase in fractionation temperature. Acid content increase along with increase in fractionation temperature

\section{References}

AOAC. 1990."Association of Official Analytical Chemistry: Official Method of Analysis, $18^{\text {th }}$ edition". Benyamin Franklin, Washington DC.

Apriyanto, A., Fardiaz, D., Puspitasari, N.L., Sedarnawati, Y., and Budianto, S. 1989. "Petunjuk Laboratorium Analisis Pangan". Pusat Antar Universitas, Institut Pertanian Bogor, Bogor.

Buckingham, J. 1982. "Dictionary of Organic Compound". Chapman and Hall, New York.

Darmadji, Purnama. 1996. Aktifitas Anti Bakteri Asap Cair dari Berbagai Limbah Pertanian. Agritech. 16(4):1419

Estrada. M.R, E.A.E. Boyle and R.J. Townsend. 1971. "Biochemistry of Foods". New York

Frazier, W.C. and Westhoff, D.C. 1983. Food Microbiology $2^{\text {nd }}$ Ed. Tata McGrow-Hall Publishing Company Limited, New Delhi. 
Girrard, J.P. 1992. "Smoking in: Technology of Meat and Meat Product". Ellis Horwood, New York.

Gorbatov, V.M., Krylova, N.N., Volovinskaya, V.P., Cyaskovkaya, Y.N., Bazarova, K.I., Khlamova, R.I., and Yakavlova, G.Y. 1971. Liquid Smokes For Use in Curred Meat. Food Tech. 25:71-77

Lappin, G.R. and Clark, L.C. 1951. Colometric Methods for Determination of Traces Carbonyl Compound. Analytical Chemistry 23:541-542.

Maga, J. A. 1987. Smoke in Food Processing. CRC Press. Inc, Boca Raton, Florida.

Pszczola, D.E., 1995. Tour Highlights Production and Uses of Smoke Base Flavors. Food Tech. 49:70-74.

Sax, N.I. and Lewis, R. Jr. 1987. Howley's Condensed Chemical Dictionary. Van Nostrand Reinhold, New York.
Senter, S.D., Robertson, J.A. and F.I. Meredith. 1989. Phenolic Compound of the Mesocarp of Cresthaven Peaches During Storage and Ripening. J. Of Food Sci. 54:1250-1268

Swastawati, F., Susanto, E., Cahyono, B. and Trilaksono, W. A. 2012. Sensory evaluation and chemicalcharacteristics of smoke stingray (dasyatis blekeery) processed by using two different liquid smoke. International Journal of Bioscience, Biochemistry, and Bioinformatics. 2(3):212-216.

Wahyono, S., Sahwan L. F., Suryanto. F and Waluyo, A. 2004. Pembuatan Kompos dari Tandan Kelapa Sawit. Prosiding Seminar Teknologi Untuk Negeri. 1:375-386. 